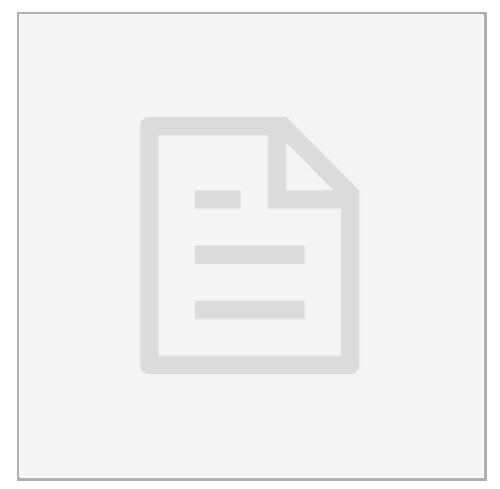

\title{
(3) Biochemical analysis of quail blood
}

\section{a PLOS One}

\author{
Gamal Mehaisen ${ }^{1}$, Ahmed O. Abass ${ }^{1}$
}

${ }^{1}$ Cairo University

SEP 03, 2018

\section{open ठaccess}

\section{DOI:}

dx.doi.org/10.17504/protocol s.io.s7yehpw

\section{External link:}

https://doi.org/10.1371/journa l. pone. 0214839

Protocol Citation: Gamal Mehaisen, Ahmed O. Abass 2018. Biochemical analysis of quail blood. protocols.io https://dx.doi.org/10.17504/p rotocols. io.s7yehpw

\section{MANUSCRIPT CITATION:}

Mehaisen GMK, Desoky AA, Sakr OG, Sallam W, Abass AO (2019) Propolis alleviates the negative effects of heat stress on egg production, egg quality, physiological and immunological aspects of laying Japanese quail. PLoS ONE 14(4): e0214839. doi: $\underline{10.1371 / \text { journal. pone. } 021483}$ $\underline{9}$

License: This is an open access protocol distributed under the terms of the Creative Commons Attribution License, which permits unrestricted use, distribution, and reproduction in any medium, provided the original author and source are credited 
Protocol status: Working

We use this protocol and it's working

Created: Sep 03, 2018

Last Modified: Sep 03, 2018

PROTOCOL integer ID:

15320

\section{Sample preparation:}

1 1. Blood samples were collected into heparinized tubes.

2. Samples were centrifuged at $2000 \mathrm{xg}$ for $10 \mathrm{~min}$ at $4^{\circ} \mathrm{C}$.

3. The plasma was separated and stored at $-20^{\circ} \mathrm{C}$ until analyzed.

\section{Lipid peroxidation (Colorimetric MDA Assay Kit, ab118970,}

2 1. Add $600 \mu \mathrm{L}$ of Thiobarbituric Acid (TBA) solution to $200 \mu \mathrm{L}$ standard and $200 \mu \mathrm{L}$ test samples.

2. Incubate TBA-standard/TBA-sample mixture at $95^{\circ} \mathrm{C}$ for 60 minutes.

3. Cool to room temperature in an ice bath for 10 minutes.

4. Pipette $200 \mu \mathrm{L}$ from each $800 \mu \mathrm{L}$ TBA-standard and TBA-sample reaction mixture into a 96 well microplate.

5. Measure plate immediately at OD532 $\mathrm{nm}$ for colorimetric assay.

\section{Alanine aminotransferase (Colometric ALT Assay Kit, Ref-2..}

3 1. Add $0.5 \mathrm{~mL}$ of $\mathrm{R} 1$ ( $100 \mathrm{mmol}$ Phosphate buffer, $200 \mathrm{mmol}$ DL-Alanine, $6 \mathrm{mmol}$ 2-Oxoglutarate, and $12 \mathrm{mmol}$ Sodium Azide) to $100 \mu \mathrm{L}$ of distilled water or test samples.

2. Mix and incubate for exactly 30 minutes at $37^{\circ} \mathrm{C}$.

3. Add $0.5 \mathrm{~mL}$ of R2 (2,4-dinitrophenyl hydrazine) to all tubes.

4. Mix and incubate for exactly 20 minutes at $20-25^{\circ} \mathrm{C}$.

5. Mix with $0.5 \mathrm{~mL}$ of sodium hydroxide $(0.4 \mathrm{~mol} / \mathrm{L})$.

6. Measure absorbance of samples against reagent blank at $546 \mathrm{~nm}$ after 5 minutes.

7. The sensitivity of this assay is $4 \mathrm{U} / \mathrm{L}$ and the analytical range is $4-94 \mathrm{U} / \mathrm{L}$.

\section{Asparate aminotransferase (Colometric AST Assay Kit, Ref-.}

4 1. Add $0.5 \mathrm{~mL}$ of $\mathrm{R} 1$ ( $100 \mathrm{mmol}$ Phosphate buffer, $100 \mathrm{mmol} \mathrm{L}$-aspartate, $5 \mathrm{mmol}$ 2-Oxoglutarate, $140 \mathrm{mmol}$ sodium hydroxide, and $12 \mathrm{mmol}$ Sodium Azide) to $100 \mu \mathrm{L}$ of distilled water or test samples.

2. Mix and incubate for exactly 30 minutes at $37^{\circ} \mathrm{C}$.

3. Add $0.5 \mathrm{~mL}$ of R2 (2 mmol 2,4-dinitrophenyl-hydrazine and $8.4 \% \mathrm{HCl})$ to all tubes. 
4. Mix and incubate for exactly 20 minutes at $20-25^{\circ} \mathrm{C}$.

5. Mix with $0.5 \mathrm{~mL}$ of sodium hydroxide $(0.4 \mathrm{~mol} / \mathrm{L})$.

6. Measure absorbance of samples against reagent blank at $546 \mathrm{~nm}$ after 5 minutes.

7. The sensitivity of this assay is $7 \mathrm{U} / \mathrm{L}$ and the analytical range is $7-89 \mathrm{U} / \mathrm{L}$.

\section{Triglycerides (GPO-PAP-enzymatic colorimetric Assay Kit, $\mathbf{R}$.}

5 1. Add $1.0 \mathrm{~mL}$ of prepared Reagent to $10 \mu \mathrm{L}$ of standard triglyceride $(200 \mathrm{mg} / \mathrm{dl})$ or test samples.

2. Mix and incubate for 5 minutes at $37^{\circ} \mathrm{C}$.

3. Measure absorbance of samples $\left(A_{s p}\right)$ and standard $\left(A_{s t}\right)$ against reagent blank at $546 \mathrm{~nm}$ within 30 minutes.

4. Triglycerides conc. $(\mathrm{mg} / \mathrm{dL})$ is calculated as $\left(A_{s p} / A_{s t}\right) \times 200$.

\section{Cholesterol (CHOD-PAP-enzymatic colorimetric Assay Kit, R.}

6 1. Add $1.0 \mathrm{~mL}$ of prepared Reagent to $10 \mu \mathrm{L}$ of standard cholesterol $(200 \mathrm{mg} / \mathrm{dl})$ or test samples.

2. Mix and incubate for 5 minutes at $37^{\circ} \mathrm{C}$.

3. Measure absorbance of samples $\left(A_{s p}\right)$ and standard $\left(A_{s t}\right)$ against reagent blank at $546 \mathrm{~nm}$ within 30 minutes.

4. Cholesterol conc. $(\mathrm{mg} / \mathrm{dL})$ is calculated as $\left(A_{s p} / A_{s t}\right) \times 200$.

\section{Calcium (O-CPC colorimetric Assay Kit, Ref-226, Spectrum D}

7 1. Mix $0.5 \mathrm{~mL}$ of R1 (0.3 mol 2-Amino-2-methyl-1-propanol, $\mathrm{pH} 10.5)$ and $0.5 \mathrm{~mL}$ of $\mathrm{R} 2$ ( $0.16 \mathrm{mmol}$ O-cresolphthalein complexone, $7 \mathrm{mmol}$ 8-hydroxyquinoline).

2. Add the mixture to $10 \mu \mathrm{L}$ of standard calcium ( $10 \mathrm{mg} / \mathrm{dl})$ or to $10 \mu \mathrm{L}$ of test samples.

3. Incubate for 5 minutes at $20-25^{\circ} \mathrm{C}$.

4. Measure absorbance of samples $\left(A_{s p}\right)$ and standard $\left(A_{s t}\right)$ against reagent blank at $578 \mathrm{~nm}$.

5. Calcium conc. $(\mathrm{mg} / \mathrm{dL})$ is calculated as $\left(\mathrm{A}_{\mathrm{sp}} / \mathrm{A}_{\mathrm{st}}\right) \times 10$.

\section{Phosphorus (UV colorimetric Assay Kit, Ref-294, Spectrum}

8 1. Add $1.0 \mathrm{~mL}$ of Reagent $(3.5 \mathrm{mmol}$ ammonium molybdate, $750 \mathrm{mmol}$ sulphuric acid, and $1 \%$ Surfactants) to $10 \mu \mathrm{L}$ of either blank reagent (distilled water), standard reagent ( $5 \mathrm{mg} / \mathrm{dl}$ phosphorus) or test samples.

2. Mix and wait for 5 minutes at $37^{\circ} \mathrm{C}$.

3. Measure absorbance of samples $\left(A_{s p}\right)$ and standard $\left(A_{s t}\right)$ against reagent blank at $340 \mathrm{~nm}$ within 30 minutes.

4. Phosphorus conc. $(\mathrm{mg} / \mathrm{dL})$ is calculated as $\left(A_{s p} / A_{s t}\right) \times 5$.

Total protein (Biuret colorimetric Assay Kit, Ref-310, Spect.. 
1. Add $1.0 \mathrm{~mL}$ of Reagent $(750 \mathrm{mmol}$ sodium hydroxide, $12 \mathrm{mmol}$ copper sulphate, $40.9 \mathrm{mmol}$ sodium potassium tartrate, and $19.8 \mathrm{mmol}$ potassium iodide) to $20 \mu \mathrm{L}$ of either standard total protein $(6 \mathrm{mg} / \mathrm{dL})$ or test samples.

2. Mix and incubate for 10 minutes at room temperature.

3. Measure absorbance of samples $\left(A_{s p}\right)$ and standard $\left(A_{s t}\right)$ against reagent blank at $546 \mathrm{~nm}$ within 30 minutes.

4. Protein conc. $(\mathrm{mg} / \mathrm{dL})$ is calculated as $\left(A_{s p} / A_{s t}\right) \times 6$.

\section{Albumin (BCG colorimetric Assay Kit, Ref-211, Spectrum Di..}

1. Add $1.0 \mathrm{~mL}$ of Reagent $(100 \mathrm{mmol}$ acetate buffer, $0.27 \mathrm{mmol}$ Bromocresol green, and detergent) to $10 \mu \mathrm{L}$ of either standard albumin ( $4 \mathrm{~g} / \mathrm{dL})$ or test samples.

2. Mix and incubate for approximately 5 minutes at $20-25^{\circ} \mathrm{C}$.

3. Measure absorbance of samples $\left(A_{s p}\right)$ and standard $\left(A_{s t}\right)$ against reagent blank at $623 \mathrm{~nm}$ within 60 minutes.

4. Protein conc. $(\mathrm{mg} / \mathrm{dL})$ is calculated as $\left(A_{s p} / A_{s t}\right) \times 4$.

\section{Corticosterone (Chicken CORT ELISA Kit, MBS701668, MyBi..}

11 1. Add $50 \mu \mathrm{L}$ of standard and sample per well.

2. Add $50 \mu$ Antibody to each well immediately.

3. Mix well with the pipette for 30 seconds and cover with the adhesive strip provided.

4. Incubate for 30 minutes at $25^{\circ} \mathrm{C}$.

5. Aspirate each well and wash with Wash Buffer $(250 \mu l)$ using a multi-channel pipette.

6. Repeat the process three times for a total of four washes.

7. After the last wash, remove any remaining Wash Buffer and blot the plate inversly against clean paper towels.

8. Add $100 \mu \mathrm{L}$ HRP-conjugate to each well immediately and cover with the adhesive strip provided.

9. Incubate for 30 minutes at $25^{\circ} \mathrm{C}$.

10. Repeat the aspiration/wash process for four times as in step 5.

11. Add $100 \mu \mathrm{L}$ of TMB Substrate to each well.

12. Incubate for 15 minutes at $25^{\circ} \mathrm{C}$, protecting from light.

13. Add $50 \mu \mathrm{L}$ of Stop Solution to each well and gently tap the plate to ensure thorough mixing.

14. Determine the optical density of each well within 5 minutes, using a microplate reader set to $450 \mathrm{~nm}, 540 \mathrm{~nm}$ or $570 \mathrm{~nm}$.

15. Subtract readings at $540 \mathrm{~nm}$ or $570 \mathrm{~nm}$ from the readings at $450 \mathrm{~nm}$.

\section{Tumor necrosis factor alpha (Chicken TNF- $\alpha$ ELISA Kit, MBS.}

1. Set a Blank well without any solution.

2. Add $50 \mu \mathrm{L}$ of standard and sample per well.

3. Add $50 \mu \mathrm{L}$ HRP-conjugate (1x) to each standard/sample wells immediately. 
4. Mix well with the pipette for 60 seconds and cover with the adhesive strip provided.

5. Incubate for 40 minutes at $37^{\circ} \mathrm{C}$.

6. Aspirate each well and wash with Wash Buffer $(250 \mu l)$ using a multi-channel pipette.

7. Repeat the process three times for a total of four washes.

8. After the last wash, remove any remaining Wash Buffer and blot the plate inversly against clean paper towels.

9. Add $90 \mu \mathrm{L}$ of TMB Substrate to each well.

10. Incubate for 20 minutes at $37^{\circ} \mathrm{C}$, protecting from light.

11. Add $50 \mu \mathrm{L}$ of Stop Solution to each well and gently tap the plate to ensure thorough mixing.

12. Determine the optical density of each well within 5 minutes, using a microplate reader set to $450 \mathrm{~nm}, 540 \mathrm{~nm}$ or $570 \mathrm{~nm}$.

13. Subtract readings at $540 \mathrm{~nm}$ or $570 \mathrm{~nm}$ from the readings at $450 \mathrm{~nm}$. 